\title{
Climate-Smart Maize
}

\begin{abstract}
In the US alone, over 85 million maize tortillas are eaten each year in everything from wraps and sandwiches to pizzas and lasagnes, and that's before all our snacking on tortilla chips is added in. While Central America is its birthplace, the US, China and Brazil are now the big maize producers-together they produce two-thirds of the global harvest. One snack bag of tortilla chips has a climate footprint of around 50 grams of greenhouse gas emissions. Even with transatlantic shipping, this footprint largely comes from growing the maize in the first place. In the UK each year we throw away an estimated 23,000 tonnes of savoury snacks, including tortilla chips. Water, too much of it and especially not enough of it, embodies the climate threat to maize production. Attack by pests and diseases may increase, with a particular concern being a rise in fungal toxins, like aflatoxin, in human and livestock food. Improved plant health through soil water management, irrigation and new varieties can each give greater resilience. Supporting maize types and cultivation practices that are specifically aligned with local contexts emerges as a core requirement of climate-smart practice.
\end{abstract}

Keywords Corn $\bullet$ Mexico $\bullet$ Chiapas $\bullet$ Tortillas $\bullet$ Masa $\bullet$ Landraces $\bullet$ Drought $\bullet$ El Nino $\bullet$ GM $\bullet$ Low-till $\bullet$ Soil organic matter $\bullet$ Aflatoxin $\bullet$ Stem borer $\bullet$ Corn borer $\bullet$ Irrigation $\bullet$ Disease resistance 
To go with my re-heated curry lunch is a crunchy bag of salted tortilla chips. Tortillas are made from maize flour and, as with so many great foods, we have Mexico to thank for these moreish snacks. The gigantic expanses of maize (or corn) grown around the world today are thought to owe their existence to a wild grass called Teosinte. Some 9,000 years ago, our ancestors in Central America collected this plant and over many generations domesticated and bred it into the bountiful cob-bearing plants we know and love today. Much of its journey from unassuming wild grass with small, hard seed cases to global giver of sweet, plump corn has been revealed using a wizened 5,000-year-old discovery. This incredibly wellpreserved ancestral corn cob was found in the 1960s and yielded DNA that showed the transformation from wild grass to maize was already well underway five millennia ago. Though the cob was much smaller and had only half the rows of kernels (the regimented pea-sized fruits of maize) common to modern plants, it carried the unmistakable genetic signposts to softer, sweeter corn [1].

Today, maize-also called corn and going by the scientific name Zea mays - is the single biggest crop in the world. Rice may be the source of nourishment for over 1.5 billion people, and wheat may cover more acres but, for sheer global tonnage, maize wins hands down. It is grown on every continent save Antarctica with annual production of over 800 million tonnes. In the US alone, over 85 million maize tortillas are eaten each year in everything from wraps and sandwiches to pizzas and lasagnes, and that's before all our snacking on tortilla chips is added in [2]. While Central America is its birthplace, the US, China and Brazil are now the big maize producers - together they produce two-thirds of the global harvest [3] (Fig. 11.1).

Maize doesn't just provide the corn on the cob beloved of barbecues or the flour for our tortilla wraps and triangular snacks. It is widely used as an animal feed and processed to make everything from sweeteners and oils to drinks and glues. By its conversion to ethanol, it is the feedstock for huge amounts of vehicle fuel too. In the US, production of corn ethanol has exploded in recent decades and now accounts for almost half of the harvest. Corn ethanol can be blended with gasoline and has been promoted as a way to reduce reliance on oil imports and so increase fuel security. In theory it could also mean lower greenhouse gas emissions by substituting fossil fuels with low carbon biofuel ethanol. As we will see, however, such a field-grown answer to high carbon transport might not be all it is cracked up to be. 


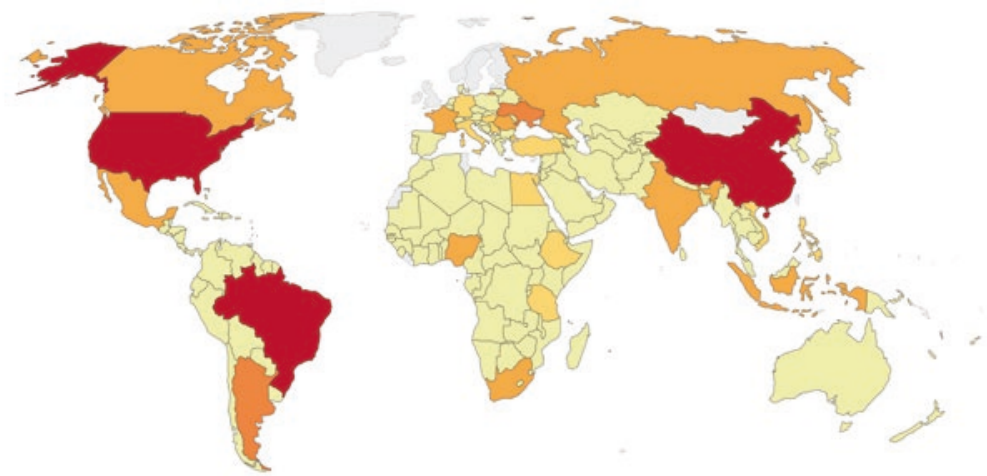

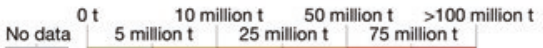

Fig. 11.1 Global maize production in 2014 by country of origin (Source: Hannah Ritchie, Our World in Data) [4]. Available at: https://ourworldindata. org/grapher/maize-production

The tightly packed kernels of maize can come in a range of different forms and colours. There is sweetcorn and popcorn, the golden yellow type common in the US and Europe, and the white maize popular in many parts of Africa. It even comes in red, blue and black [5]. Our own salty lunchtime treat began life as corn grown in the fields of Chiapas State in the far south of Mexico [6]. Many centuries may have passed since the first cobs were harvested in those sun-drenched fields, but the process of turning them into crunchy snacks has changed little.

The main crop of maize in Mexico is sown in late spring and summer and then harvested over autumn and winter [7]. Waterlogged soils pose a risk during the early stages as they can mean the seedlings rot before they emerge from the ground. Maize plants like it warm-ideally an average daily temperature of at least 19 degrees Celsius and with summertime temperatures over 23 degrees Celsius - so cold weather may also be a problem. The young plants are especially susceptible to frost damage and even short periods of chill will slow growth and increase the chances of fungal attack. 
After about ten weeks the plants should have grown into a towering stand 12 feet or more in height. The kernels begin to develop and the cobs to swell. It is here that dry conditions and water stress can be dangerous, as they can mean pollination is poor and development of the cobs is delayed. Just four days of water stress at this critical time can cut eventual yields in half $[8,9]$. Severe hailstorms or hard frosts are even more disastrous, stripping the leaves from the plants or rupturing plant cells with ice crystals. Either risk destroying the whole crop in one fell swoop.

Finally, at around six months after sowing, the leaves on the now heavily laden plants will brown and the precious corn cobs will hopefully be ripe for harvest [9]. Frost is now no longer a risk, but lodging (falling over) of plants due to disease, pests or severe weather is. The sweet kernels need to have dried to the right moisture content (around 30 per cent) before they are harvested to avoid mould growth, and even then, they need to be further dried if they are to be stored for an extended period.

After harvest the corn destined to be our premium tortilla chips must first be made into a coarse dough or masa. A mixture of corn, water and foodgrade lime (to remove the skins on the corn kernels and give a longer shelf life) is cooked up together in large steam kettles while being constantly agitated through injections of steam and compressed air. After cooking in this lime solution (called nixtamalisation), the mixture is rapidly cooled and allowed to steep to get rid of the skins and to soften the kernels. A thorough wash and drain, and then it's into the grinding room where heavy stones made from hard volcanic rock mash the mixture into the coarse masa that is needed. If destined for foreign markets, like the snack manufacturers of Europe, it is dried and graded into flour before being packaged up and sent by ship across the Atlantic. On arrival the flour is rewetted into dough and the raw chips are rolled and cut before being baked, cooled, and fried and seasoned. Our snappy tortilla chips are then ready for eating [10].

One snack bag of tortilla chips has a climate footprint of around 50 grams of greenhouse gas emissions. Even with transatlantic shipping, this footprint largely comes from growing the maize in the first place. Emissions of nitrous oxide from adding fertilisers to the soils again dominate, making up around one-third of the total. Some also occur via the energy used in making fertilisers, pesticides and herbicides, and from operating farm machinery, artificial irrigation or corn drying equipment [11]. Once harvested, the electricity and gas used for processing the corn into masa are important sources of emissions, with oil for frying, packaging and of course transport each adding to the overall total. 
Our appetite for savoury snacks like tortilla chips seems boundless. Global sales are predicted to top $£ 100$ billion by 2020 , with the average person in the UK already tucking away around 7 kilograms of snacks a year, rising to a thirst-inducing 9.5 kilograms per person each year in the US [12]. Issues of dietary health and expanding waistlines aside, meeting such rising demand for maize and other crops will mean increasing greenhouse gas emissions unless global production becomes more climatesmart. Alongside the hidden 'wastage' that is overconsumption of food comes the more overt waste of tortillas and maize snacks that means huge amounts of land cultivation and emissions for no ultimate benefit. It should by now be a familiar story.

As the tortilla chips we buy from the shops are usually well wrapped and preserved, they can have a good long shelf life. Like many snack foods, however, once opened, the race to beat staleness and waste begins. In the UK each year we throw away an estimated 23,000 tonnes of savoury snacks, including tortilla chips [13]. Almost all of this is deemed avoidable and mostly results from the snacks not being eaten in time or from too much being served. While still some way behind potato crisps as Britain's favourite snack, tortilla chips have become a mainstay of the weekly shopping basket and represent a global business worth over $\$ 10$ billion [14]. As with all the foods and drinks we've followed so far, avoiding wastage has the potential to save thousands of tonnes of emissions. For our tasty maize-based snacks, buying and serving only what is really needed, storing them in air-tight packets once opened and keeping an eye on use-by dates will all go a long way to realising this potential.

Water, too much of it and especially not enough of it, embodies the climate threat to Mexican maize production. The drought conditions caused by the El Nino of 1998 knocked a quarter of the annual harvest, while the wetter more humid years of 1991 to 1993 provided bumper crops [15]. The region of Chiapas and its indigenous farmers in southern Mexico are no strangers to such variability. For generations they have had to cope with the vagaries of El Nino and La Nina-those fluctuating states of warm and cold waters in the Pacific Ocean that drive big swings in temperature and even bigger swings in rainfall patterns over large swathes of the world.

Traditionally Chiapas farmers have grown maize alongside beans, using their crops to feed themselves and their families rather than the international 
snack trade. Maize occupies half of all the land used for agriculture in the region and is worth an estimated $\$ 400$ million each year. The individual farms are often very small though-many have been divided and subdivided several times as they are passed down from one generation to the next. They can also be very poor. Per hectare, average maize yields in Chiapas are two-thirds that of Mexico as a whole with access to financial and technical support limited and only 1 farmer in 25 using irrigation [16].

Drought has been a common feature of the past decade. Severe drought gripped much of Mexico during both 2011 and 2012, with maize farmers in the north being particularly badly hit and the national maize harvest falling by several million tonnes [17]. In the powerful El Nino year of 2016, Chiapas itself endured such an extreme drought that water levels in its Nezahualcóyotl reservoir dropped by 25 metres and a sixteenth century church not seen for a generation emerged [18]. With so few farms having access to irrigation, any major decrease in rainfall due to climate change ramps up the risk of widespread crop losses. As early as 2030 annual rainfall in the region is predicted to decrease by between 6 and $53 \mathrm{~mm}$, alongside average temperature increases of over 1.5 degrees Celsius [16].

For the 20 million people in Mexico who rely on rain-fed maize as their staple food, this trend towards drier conditions through the century strikes at the very heart of food security. Just how big the impacts will be depends to a large extent on which emissions pathway global society decides to take. With deep and rapid actions that limit global average temperature increase to around 2 degrees Celsius, some areas of Mexico-such as central and northwest states-could see wetter conditions and higher yields. However with further growth in global emissions, and warming of 4 degrees Celsius or more [19], most states are predicted to experience much drier conditions and precipitous drops in maize yields. For some, including Chiapas, it would spell disaster-yields there could drop by a famine-inducing 80 per cent [15].

Damage from tropical cyclones may also increase as higher sea surface temperatures enhance the intensity of storms. Likewise, more extreme rainfall events and persistent flooding of fields bring with them the threat of complete loss of crops as seedlings and young plants rot in the waterlogged soils [16]. Even where such severe weather impacts do not destroy crops directly, they may open the plants up to more attack from pests and diseases. Climate change, it seems, is shaping up to give the world's biggest crop some very hard falls. 
Between 1988 and 1990, an estimated $\$ 44$ billion-worth of maize was produced around the world, but a further $\$ 27$ billion-worth was lost due to disease, pests and weeds [8]. In North America, there is now concern that the ranges of the most damaging maize pests - the corn borer, the corn earworm and the corn rootworm-may all expand as winters become milder [20]. An inspired response to another of these rampant maize pests (the stem borer) has been one championed by smallholders in Uganda. It's called push-pull.

This clever combination of companion planting with maize involves growing stands of tall Napier grass around the plots of maize. In amongst the maize itself, a low-growing nitrogen-fixing plant called Desmodium is also grown. The Desmodium enriches the soil and suppresses weeds while releasing a chemical that repels the stem borer moths (the push). Meanwhile the Napier grass releases a chemical that attracts the moths (the pull). When the stem borer moths lay their eggs on the Napier grass, the grubs that hatch are quickly smothered by the strong sap of the grasses while the maize crop can grow on free of the stem borer. Using this system not only boosts maize yields but also provides three crops instead of onethe Napier grass and the Desmodium both provide good fodder for livestock [21].

Like some maize pests, fungal diseases may benefit from a changing climate too. Warmer and more humid conditions allow faster reproduction and spread of spores. As maize plants reach maturity, any waterlogging of the soils can provide ideal growing conditions for damaging fungal diseases such as the delightfully named 'crazy top' and 'common smut'. Another, called maize ear rot, thrives in the hotter drier conditions predicted for much of Mexico [22].

Not only do fungal attacks put at risk the size of the crop, they can also endanger the lives of anyone that then eats it. Some fungi naturally produce toxins as they grow on fruits, nuts, and cereal grains [23]. These mycotoxins can contaminate the crop in the field or during storage and transport after harvest. Globally they are responsible for numerous deaths and incidences of disease, including liver cancer and immune suppression [24].

One type that commonly affects maize is called aflatoxin, and it is very dangerous indeed. Aflatoxin is one of the most potent naturally occurring liver carcinogens known and, in large doses, it is deadly [24]. Initial symptoms of poisoning include abdominal pain and vomiting, with chronic exposure associated with stunted growth in children. An outbreak 
in Kenya in early 2004 killed 125 of the 317 people affected. Contaminated maize was identified as the source, with many of the affected households having stored wet maize in their homes and so increased the risk of fungal growth [23].

Another group of mycotoxins common to maize are the fumonisins. These are produced by Fusarium fungi and have been linked to oesophageal cancer and birth defects in humans, and to liver and kidney toxicity in animals. Because of the great danger it poses, mycotoxin contamination is strictly regulated in much of the world. Grain harvests are regularly screened to ensure they are within safe toxin levels and, if not, are used for non-human consumption or destroyed. In the US this destruction of contaminated food costs over $\$ 1$ billion a year, with maize farmers bearing the brunt of losses.

In Mexico too there are defined limits on aflatoxin contamination levels-a low one for maize destined for human consumption and higher limits for that used as livestock feed. In 1989, the testing of the maize in the northeastern state of Tamaulipas revealed that almost the entire 60 thousand tonne harvest had aflatoxin concentrations far above the level permitted for human consumption. Following many failed attempts to remove the toxins, the contaminated maize was instead used to make alcohol. Down in Chiapas there has been concern that the drinking of Pozol-a foamy fermentation of maize popular with indigenous inhabitants-may also pose aflatoxin dangers. Thankfully, the testing of Pozol from over 100 local markets found only 1 to have concentrations above the recommended level [25].

How exactly a future climate will change mycotoxin risks in Mexico remains unclear. Higher temperatures favour infection by fungi like Aspergillus flavus that are known to produce aflatoxins [24]. Warmer winters may also promote maize pests, such as the dusky sap beetles of the US corn belt, that carry fungal diseases from plant to plant. Certainly the warning for the US is that mycotoxin concentrations in maize are set to increase. Down in Mexico the maize farmers and Pozol drinkers of Chiapas could well be at even greater risk.

With drought being the prime climate change threat for so many Mexican maize farmers, a transition from rain-fed to irrigated farming seems an obvious response. In southern states like Chiapas, over two million 
hectares of usable farm land sits uncultivated through the dry autumn and winter months, and the Mexican Government has itself highlighted the urgent need for investment to upgrade irrigation systems and embed resilience [26]. Irrigation could allow unused lands to become productive farms, could expand the number of harvests in dry areas from one into two each year and might provide growers with the vital bridge they need to span the expanding periods between one wet season and the next.

The potential is huge. Experiments using fully irrigated maize in Chiapas have delivered yields of up to ten tonnes per hectare-five times the level commonly achieved by smallholders at the moment. The task of ensuring access to irrigation for the tens of thousands of rain-fed maize farmers across southern Mexico is similarly gargantuan. Electricity supplies would need to be extended to power a new network of water pumps, reservoirs would need to be extended, and the expanding draw on water resources in the South would need to be balanced with growing water demands further north as drought conditions begin to bite there too. Across the whole country the efficiency with which water is used will need to improve radically-in some districts that already use irrigation, the water use efficiency currently sits at a low and very leaky 37 per cent.

Even in the absence of irrigation, there are strategies that can help. Around one-quarter of farmers have taken to planting leguminous cover crops-nitrogen-fixing crops like beans that are grown in rotation with the maize, reduce soil erosion in heavy rains, and can be ploughed into the soil to give a boost to its fertility [16]. More than half of maize growers have adopted 'minimum tillage', where the reduced soil disturbance helps the retention of organic matter and water below the surface. This approach has been successful on larger farms with flat land and access to specialised planting machinery, but it could compound problems on smaller farms. In southern Mexico an array of native breeds adapted for local conditions (called 'landraces') are commonly grown, and these often have weaker roots than the new commercial varieties. Minimum tillage makes it harder to plant seeds deep enough and can also mean more rain runs off the surface of sloping fields. For those without planting machinery or with hillside farms, it therefore runs the risk of increasing climate vulnerability instead of reducing it.

Encouraging smallholders to switch away from traditional maize varieties to higher-yielding hybrids has long been seen as the way in which Mexico could boost harvests-especially if combined with greater levels of access to fertilisers, irrigation and machinery. Despite large investments, 
the success of such programmes has been limited. Many farmers appear reluctant to give up their native landraces. They may well be right. The locally adapted characteristics of native plants could provide more resilience to future drought, flood and pest risks than some of the new 'highyield' varieties.

Genetically modified or transgenic maize has been touted as a way to ensure both higher yields and the much-needed resilience in a future climate, allowing deliberate selection of traits like pest and disease resistance [27]. In theory, transgenic maize could be developed for an optimal fit with current and future growing conditions. In reality, those conditions are locally specific and widespread replacement of native varieties with just one or two transgenic crops risks losing the very diversity that is the backbone of resilience.

Instead of GM varieties and the broad-brush application of higher-yield hybrids, a more nuanced approach to boosting harvests in a changing climate has been suggested. Here, the many native landraces (over 50 have been identified) and the myriad attributes they have developed for success in local contexts are made full use of [28]. By identifying features in specific landraces that could enhance climate change resilience in a certain area, and then ensuring farmers there have access to it, truly climate-smart maize production is possible. Such a system requires detailed climate projections, seed banks and plant breeding facilities [29], alongside an established framework for farmer interaction and consultation. As ever, strong and well-funded extension services would be crucial in understanding local contexts and providing access to the right seeds at the right times [28]. There is already precedent for this.

Mexico's 'PROEMAR' project delivered impressive gains in maize yields for the farmers involved. Even in poor-weather years harvests ballooned by over 50 per cent and average output per hectare hit more than eight tonnes. This programme concentrated on improving extension services for smallholders, including soil testing and assistance with precision fertiliser application. Farmers were trained in good practice for seed treatment and sowing, improved planting densities, and how best to balance fertilisers with the needs of the plants as they grew (helping to reduce costs, nitrous oxide emissions and pollution of drainage waters) [26]. Such integrated approaches can extend well beyond the maize fields themselves. To address the threat posed by post-harvest spoilage, and especially that of mycotoxins, more climate-resilient grain storage is now 
being championed alongside improvements to supply chains and access to markets [30].

The barriers to realising these kinds of successes for all farmers in Mexico, as the twenty-first century progresses, are formidable. The UN's Food and Agriculture Organisation identified low productivity, low organisational capacity in farmers' organisations and poor access to financial products as the central ones that must be overcome [16]. They highlight the need for agricultural insurance (to protect livelihoods in bad years), early warning systems (to allow proactive responses to severe weather events like droughts), and an increase in the overall awareness of climatesmart technology and management options. Investment in capacity and support can deliver big returns-PROEMAR used $\$ 1.7$ million to provide income gains of $\$ 9.3$ million for its farmers.

There is a popular saying in the maize-growing heartlands of Mexico: ‘Sin Maíz No Hay País!'- 'Without Corn There is No Country!' [31]. Climate change poses an existential threat to the maize farmers of Mexico. With sufficient support, climate-smart strategies could help safeguard this staple food source for millions and underpin the future of the country itself.

\section{REFERENCES}

1. Briggs, H. Ancient corn cob shows how maize conquered the world. $B B C$ Online. https://www.bbc.co.uk/news/science-environment-37999506 (2016).

2. Weber, R. J. Shelf Life Extension of Corn Tortillas. Masters dissertation, Kansas State University. https://core.ac.uk/download/pdf/5165140.pdf (2008).

3. Ranum, P., Peña-Rosas, J. P. \& Garcia-Casal, M. N. Global maize production, utilization, and consumption. Ann. N. Y. Acad. Sci. 1312, 105-112 (2014).

4. Ritchie, H. Global maize production, 2014. Ourworldindata.org. https:// ourworldindata.org/grapher/maize-production (2018).

5. O'Leary, M. Maize: From Mexico to the world. CIMMYT.org. https://www. cimmyt.org/maize-from-mexico-to-the-world/ (2016).

6. Sweeney, S., Steigerwald, D. G., Davenport, F. \& Eakin, H. Mexican maize production: Evolving organizational and spatial structures since 1980. Appl. Geogr. 39, 78-92 (2013).

7. FAO. Mexico. GIEWS-Global Information and Early Warning System. http://www.fao.org/giews/countrybrief/country.jsp?code=MEX (2018).

8. Rosenzweig, C., Iglesias, A., Yang, X., Epstein, P. R. \& Chivian, E. Climate change and extreme weather events; implications for food production, plant diseases, and pests. Glob. Chang. Hum. Health 2, 90-104 (2001). 
9. Darby, H. \& Lauer, J. Critical Stages in the Life of a Corn Plant. University of Wisconsin Extension. http://corn.agronomy.wisc.edu/Management/pdfs / CriticalStages.pdf (2018).

10. madehow.com. Tortilla Chip. http://www.madehow.com/Volume-1/ Tortilla-Chip.html (2018).

11. Grant, T. \& Beer, T. Life cycle assessment of greenhouse gas emissions from irrigated maize and their significance in the value chain. Aust. J. Exp. Agri. 48, 375-381 (2008).

12. Stones, M. Global savoury snacks sales to hit $£ 103$ bn by 2020 . foodmanufacture.com. https://www.foodmanufacture.co.uk/Article/2016/09/08/ Global-snack-food-market-valued-at-103-bn-by-2020 (2016).

13. WRAP. Household food and drink waste in the United Kingdom 2012. Waste and Resource Action Programme. http://www.wrap.org.uk/sites/files/wrap/ hhfdw-2012-main.pdf.pdf (2013).

14. Euromonitor.com. What's New in Sweet and Savoury Snacks. https://blog. euromonitor.com/whats-new-in-sweet-and-savoury-snacks-opportunitiesabound-for-a-new-wave-of-products / (2015).

15. Murray-Tortarolo, G. N., Jaramillo, V. J. \& Larsen, J. Food security and climate change: The case of rainfed maize production in Mexico. Agri. For. Meteorol. 253, 124-131 (2018).

16. CIAT. Climate-Smart Agriculture in Chiapas, Mexico. CSA Country Profiles for Latin America Series. Washington, DC: The World Bank Group. http:// sdwebx.worldbank.org/climateportal/doc/agricultureProfiles/CSA-inChiapas-Mexico.pdf (2014).

17. Torres, N. Mexican farmers suffer worst drought in 70 years. Reuters. https:// www.reuters.com/article/us-mexico-drought/mexican-farmers-suffer-worstdrought-in-70-years-idUSTRE7AO18Q20111126 (2011).

18. UNISDR. Drought-hit Chiapas Leads on Sendai. https://www.unisdr.org/ archive/49048 (2016).

19. Carbonbrief. Mapped: How every part of the world has warmed-And could continue to warm. Carbonbrief.org. https://www.carbonbrief.org/mappedhow-every-part-of-the-world-has-warmed-and-could-continue-to-warm (2018).

20. Diffenbaugh, N. S., Krupke, C. H., White, M. A. \& Alexander, C. E. Global warming presents new challenges for maize pest management. Environ. Res. Lett. 3, 044007 (2008).

21. Pickett, J. A., Woodcock, C. M., Midega, C. A. \& Khan, Z. R. Push-pull farming systems. Curr. Opin. Biotechnol. 26, 125-132 (2014).

22. Doohan, F., Brennan, J. \& Cooke, B. Epidemiology of Mycotoxin Producing Fungi 755-768 (Springer, 2003).

23. WHO. Mycotoxins. http://www.who.int/news-room/fact-sheets/detail/ mycotoxins (2018). 
24. Wu, F. et al. Climate change impacts on mycotoxin risks in US maize. World Mycotoxin J. 4, 79-93 (2011).

25. García, S. \& Heredia, N. Mycotoxins in Mexico: Epidemiology, management, and control strategies. Mycopathologia 162, 255-264 (2006).

26. Fernández, A. T., Wise, T. A. \& Garvey, E. Achieving Mexico's Maize Potential (Tufts University, 2012).

27. Dalton, R. Mexico's transgenic maize under fire. Nature 462, 404 (2009). https://www.nature.com/news/2009/091125/full/462404a.html.

28. Hellin, J., Bellon, M. R. \& Hearne, S. J. Maize landraces and adaptation to climate change in Mexico. J. Crop Improv. 28, 484-501 (2014).

29. O'Leary, M. Maize: From Mexico to the world. cimmyt.org. https://www. cimmyt.org/maize-from-mexico-to-the-world/ (2016).

30. FAO. Modernizing for Growth: The Case of Grain Storage in Mexico. http:// www.fao.org/in-action/agronoticias/detail/en/c/1118464/(2018).

31. McCune, N. M. et al. Sustainable Development-Authoritative and Leading Edge Content for Environmental Management (InTech, 2012).

Open Access This chapter is licensed under the terms of the Creative Commons Attribution 4.0 International License (http://creativecommons.org/licenses/ by $/ 4.0 /$ ), which permits use, sharing, adaptation, distribution and reproduction in any medium or format, as long as you give appropriate credit to the original author(s) and the source, provide a link to the Creative Commons licence and indicate if changes were made.

The images or other third party material in this chapter are included in the chapter's Creative Commons licence, unless indicated otherwise in a credit line to the material. If material is not included in the chapter's Creative Commons licence and your intended use is not permitted by statutory regulation or exceeds the permitted use, you will need to obtain permission directly from the copyright holder.

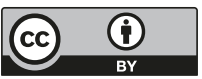

